\title{
Transformasi Politik Islam di Indonesia dalam Sistem Demokrasi
}

\author{
Fahmy Lukman ${ }^{1 *}$ \\ ${ }^{1}$ Departemen of Linguistic, Faculty of Cultural sciences, Universitas Padjadjaran, Bandung, Indonesia
}

ARTICLE INFO

\author{
Keywords \\ Transformasi, Politik, \\ Islam, Demokrasi
}

\section{*Correspondence \\ fahmylukman64@gmail.com}

\section{Article History}

Received 31 March 2018

Accepted 28 April 2018

Published on-line 10 May 2018

\section{ABSTRACT}

\section{PENDAHULUAN}

William Blum, dalam pengantar bukunya memberikan gambaran terhadap politik Amerika dalam kaitannya dengan demokrasi dengan, "For over sixty-five years, the United States war machine has been on automatic pilot. Since World War II we have been conditioned to believe that America's motives in 'exporting' democracy are honorable, even noble...argues that nothing could be further from the truth. Moreover, unless this fallacy is unlearned, and until people understand fully the worldwide suffering American policy has caused, we will never be able to stop the monster" (2013: i). Pada aspek lain, Blum (2013) memberikan beberapa catatan penting terhadap kebijakan politik luar negeri Amerika melalui propaganda demokrasi yang bertujuan mendominasi dunia. Amerika menempuh berbagai cara mencapai tujuannya. Di antara catatan buruk politik Amerika pasca berakhirnya perang dunia II adalah (1) Menggulingkan lebih dari 50 pemerintahan yang dipilih secara demokratis di luar negeri. (2) Mencampuri urusan Pemilu lebih dari 30 negara. (3) Melakukan percobaan pembunuhan terhadap lebih dari 50 pemimpin negara asing. (4) Membom penduduk sipil di lebih dari 30 negara. (5) Mengendalikan gerakan rakyat atau nasionalis di 20 negara (6) Melakukan pembunuhan jutaan orang pada lebih dari 1/3 negara dunia. (7) Bertanggungjawab atas penyiksaan terhadap ribuan orang di lebih 70 negara.

Menurut Blum, Amerika melakukan itu semua bukan karena hendak membangun demokrasi yang berasaskan pada kebebasan, berkeadilan, mengurangi kemiskinan, dan kekerasan, melainkan karena motif ekonomi dan ideologi. Amerika tidak terlalu peduli dengan demokrasi, meskipun setiap presiden Amerika selalu menggunakan kata "demokrasi" dalam setiap pidatonya. Blum menjelaskan, sesering apapun Presiden Amerika Serikat menggunakan kata demokrasi dalam setiap pidatonya. "Yang mereka pikirkan adalah memastikan negara sasaran tersebut memiliki mekanisme-mekanisme politik, keuangan, serta hukum yang sesuai dan ramah terhadap globalisasi korporasi". Dalam hal ini, instrument penting yang digunakan Amerika untuk mengendalikan dan mendominasi dunia adalah Marshall Plan terutama berkaitan dengan bantuan luar negeri yang diberikan kepada negara lain, no free lunch. Pada akhir buku itu dengan judul But What Can We Do?, Blum menyatakan, ... Our present world is in just as great peril, even more so when one considers the impending environmental catastrophe. The Bush [and now Obama] fascist tide must be stopped (2013: 337). Gelombang fasisme yang dilakukan Amerika harus segera dihentikan.

Senada dengan Blum, kritik Noam Choamsky terhadap praktik demokrasi Amerika sangat tajam saat diwawancarai David Barsamian tahun 1994. Wawancara tersebut kemudian dibukukan dengan judul Secrets, Lies and Democracy. Menurut Choamsky,

(C) 2018 by the authors; Association of Indonesian Moslem Scholar, Hannover, Germany. This is an Open Access article distributed under the terms of the Creative Commons Attribution-ShareAlike 4.0 International License. (https://creativecommons.org/licenses/by-sa/4.0/), which permits unrestricted use, distribution, and reproduction in any medium, provided the original work is properly cited. 
JKPIs, Vol. 1 No. $1,2018 \mid 2$

politik demokrasi Amerika telah memarjinalkan keterlibatan masyarakat dalam perencanaan dan implementasi kebijakan publik. Demokrasi Amerika lebih berpihak dan merefleksikan kepentingan para pengusaha dan bisnis. Bahkan, negara telah dikendalikan para investor yang bergabung dengan para politisi berkolaborasi dalam politik untuk kepentingan mereka bersama (simbiosis mutualisme). Dengan mengutip pernyataan Thomas Ferguson, ia menyatakan demokrasi Amerika sebagai "the investment theory of politics". He believes that the state is controlled by coalitions of investors who join around some common interest. To participate in the political arena, you must have enough resources and private power to become part of such a coalition. Over long periods, the involvement of the public in planning or implementation of public policy has been quite marginal. This is a business-run society. The political parties have reflected business interests for a long time (1994:5).

Dalam kaitan dengan demokrasi yang berjalan di Indonesia, Muhammad Ali Azhar (2012: 45) menyatakan, "Memang tidak semua pengusaha yang berpolitik berdampak negatif. Namun pengalaman empirik di negara berkembang menunjukkan, kemungkinan tabiat koruptif dari dwifungsi itu justru semakin membesar. Karena umumnya, motivasi utama para pengusaha atau 'taipan' berpolitik guna mempertahankan kepentingan bisnisnya (Harris, 2003). Tracking yang dilakukan menunjukkan, pebisnis di negara berkembang yang berpolitik adalah kroni kapitalis, bukan entrepreneur sejati. 'Kerajaan' bisnis yang dibangun bukan hasil persaingan usaha sehat dan inovasi bisnis, tetapi dari privilege dan konsesi yang diberikan patron politik. Yashiro Kunio (1990) menamakannya "kapitalis semu" (ersatz kapitalism), yaitu pengusaha yang tumbuh karena memiliki hubungan mesra dengan rezim. Dampak simbiosis mutualisme penguasa dan pengusaha dalam sistem demokrasi adalah tumpulnya mekanisme kontrol lembaga-lembaga politik terhadap berbagai kebijakan penguasa. Kekuasaan cenderung menjadi abuse of power dan penyelewengan mandat rakyat karena kepentingan bisnis dan pengusaha.

Berdasarkan aspek di atas terdapat persoalan mendasar dengan demokrasi dalam kaitan praktik demokrasi baik dalam negara berkembang maupun maju. Tentu saja hal itu menjadi penting untuk ditelaah secara mendalam karena hal itu terdapat kemungkinan berkorelasi dengan pemahaman mendasar demokrasi secara teoretis-konseptual. Penting pula untuk dikomparasikan bagaimana hubungan demokrasi dengan Islam karena pada realitasnya banyak sekali pendapat yang menyatakan bahwa jiwa Islam terdapat dalam demokrasi dan Islam itu sangat menghormati demokrasi.

\section{KRITIK TERHADAP DEMOKRASI}

Berdasarkan pendapat para ahli tentang demokrasi dinyatakan bahwa inti demokrasi adalah kedaulatan berada di tangan rakyat dengan slogan dari rakyat, oleh rakyat, untuk rakyat. Menurut KBBI, demokrasi merupakan (1) bentuk atau sistem pemerintahan yang seluruh rakyatnya turut serta memerintah dengan perantaraan wakilnya; pemerintahan rakyat; (2) gagasan atau pandangan hidup yang mengutamakan persamaan hak dan kewajiban serta perlakuan yang sama bagi semua warga negara (https://kbbi.web.id/demokrasi).

Mengacu pada pengertian di atas, kritik terhadap demokrasi dapat dilihat pada hal berikut.

\subsection{Berdasarkan praktik demokrasi yang terjadi di berbagai negara penganut demokrasi, seperti Amerika, Inggris, Perancis, Korea selatan, termasuk Indonesia.}

Fakta menunjukkan bahwa para wakil rakyat dan kepala negara di negara-negara demokrasi tersebut pada hakikatnya mewakili para pemilik modal. Sebabnya adalah para pemilik modal inilah yang membiayai para politisi, dari kampanye sampai proses pemilihan wakil rakyat dan presiden. Hubungan simbiosis yang signifikansi tentu berpengaruh terhadap para politisi baik eksekutif, legislatif, maupun yudikatif. Di Inggris, sebagian besar anggota parlemen ini mewakili para penguasa, pemilik tanah, serta golongan bangsawan aristokrat.

Berkaitan dengan hal itu, Gaetano Mosca (1858-1941), Vilfredo Pareto (1848-1923), Robert Michels (1876-1936), dan Max Weber (1864-1920) cenderung melihat demokrasi sebagai topeng ideologis yang melindungi tirani minoritas atas mayoritas. Dalam praktiknya, yang berkuasa adalah sekelompok kecil atas kelompok besar yang lain. Seperti di Indonesia, mayoritas kaum Muslim Indonesia berada dalam posisi yang kurang menguntungkan. Indonesia lebih didominasi oleh kelompok minoritas, terutama dalam hal kekuasaan (power) dan kepemilikan modal (kapital). Kritik yang sama muncul dari C. Wright Mills yang memfokuskan penelitiannya pada persoalan elit politik. Berdasarkan penelitiannya pada sebuah kota kecil di AS, dia melihat bahwa meskipun pemilu dilakukan secara demokratis, ternyata elit penguasa yang ada selalu datang dari kelompok yang sama. Kelompok ini merupakan kelompok elit di daerah tersebut yang menguasai jabatan-jabatan negara, militer, dan posisi kunci perekonomian. Mereka pun datang dari keluarga-keluarga kaya di daerah tersebut, yang mengirimkan anak-anak mereka ke sekolah-sekolah elit yang sama. Memang, secara ide, demokrasi sering menyatakan bahwa semua orang bisa menempati jabatan negara, militer, atau memegang posisi bisnis kelas atas. Akan tetapi, dalam kenyataannya, jabatan-jabatan itu diduduki oleh kelompok-kelompok tertentu.

Pendukung demokrasi bangga dengan menyatakan bahwa dalam demokrasi setiap keputusan yang diambil adalah suara mayoritas rakyat. Namun, kenyataannya tidaklah begitu. Tetap saja keputusan diambil oleh sekelompok orang yang berkuasa, yang memiliki modal besar, kelompok berpengaruh dari keluarga bangsawan, atau dari militer.

Dalam sistem demokrasi sebagai landasan kapitalisme, kekuatan pemilik modal menjadi faktor yang sangat penting dalam pengambilan keputusan, bukan rakyat secara keseluruhan. Merekalah yang banyak mempengaruhi pengambilan keputusan di parlemen atau pemerintahan. Hal ini karena dalam sistem kapitalis, calon anggota parlemen haruslah memiliki modal yang besar untuk mencalonkan diri. Karena itu, jika dia bukan pengusaha kaya, dia akan dicalonkan atau disponsori oleh para pengusaha kaya, sehingga money politic merupakan keniscayaan. Bisa disebut hampir mustahil, kalau ada orang bisa mencalonkan diri menjadi presiden atau anggota parlemen kalau tidak memiliki modal. Karena itu, keputusan yang diambil oleh parlemen hampir dapat dipastikan memihak para pemilik. Legalisasi serangan Amerika ke Irak oleh parlemen sangat berhubungan dengan kepentingan ekonomi para pengusaha minyak AS. Irak memiliki cadangan minyak kedua terbesar setelah Saudi Arabia. Dalam sejarah Inggris, PM Anthony Eden, misalnya, bahkan pernah mengumumkan perang terhadap Mesir dalam krisis Suez tanpa terlebih dulu meminta persetujuan parlemen. Begitu pula, serangan Amerika terhadap negara-negara lain seperti Irak, Afganistan, Sudan, Libya, Somalia; sering tanpa persetujuan parlemen. 
JKPIs, Vol. 1 No. 1, 2018 |3

Fakta dalam demokrasi, sulit untuk membuat keputusan dengan terlebih dulu mendapat persetujuan rakyat. Bisa disebut, klaim 'suara anggota parlemen adalah cerminan suara rakyat' hanyalah mitos. Seharusnya, kalau prinsip ini dilaksanakan, setiap kali parlemen akan menghasilkan sebuah UU atau kebijakan, mereka bertanya dulu kepada rakyat, bagaimana pendapat mereka. Tentu cara seperti ini sangat sulit, untuk tidak dikatakan utopis. Apalagi, kalau negara tersebut memiliki jumlah penduduk yang sangat besar seperti AS dan Indonesia.

\subsection{Demokrasi adalah pemerintahan rakyat.}

Anggapan ini keliru dan utopis. Pada praktiknya, tidak mungkin seluruh rakyat memerintah. Tetap saja yang menjalankan pemerintahan adalah elit penguasa yang berasal dari para pemilik modal kuat dan atau pengendali kekuatan militer.

\subsection{Demokrasi dan kebebasan.}

Bagi pendukung demokrasi, kebebasan berpendapat (freedom of speech) dianggap sebagai salah satu nilai unggul dan luhur demokrasi. Faktanya bahwa dalam negara demokrasi, kebebasan berpendapat dibatasi oleh demokrasi itu sendiri. Artinya, pendapat yang dianggap bertentangan dengan nilai-nilai demokrasi atau akan menghancurkan sistem demokrasi tetap dilarang. Organisasi atau partai politik dalam demokrasi adalah yang sejalan dengan demokrasi. Jika bertentangan tetap dilarang. Sebenarnya dalam sistem apapun, wajar jika sebuah sistem politik memiliki batasan yang tidak boleh dilanggar, apalagi sampai menghancurkan sistem politik itu. Hanya saja, pendukung demokrasi, sering mengklaim bahwa hanya demokrasi yang membolehkan kebebasan berpendapat, sementara sistem ideologi lain tidak ada kebebasan tersebut. Padahal dalam kenyataannya, sistem demokrasi pun memberikan batasan tentang kebebasan berpendapat ini. Sebagai contoh, di Perancis dan beberapa negara lainya di Eropa, jilbab dilarang atau paling tidak dihambat pemakainya atas nama sekularisme (yang merupakan asas dari sistem demokrasi). Begitu pula saat kelompok Islam yang memperjuangkan aspirasinya tentang hukum Islam itu menjadi terlarang dan bahkan kelompok Islam yang dianggap bertentangan dengan sekularisme kemudian dikaitkan dengan tindakan terorisme. Atas nama perang melawan terorisme, kebebasan media masa dihambat, baik oleh negara ataupun oleh kesadaran media itu sendiri.

\subsection{Demokrasi dan kesejahteraan.}

Banyak penganut sekularisme memandang bahwa demokrasi akan membawa kesejahteraan bagi dunia. Hal ini sering dipropagandakan oleh negara-negara Barat kepada Dunia Ketiga supaya mereka mau dan setia menerapkan sistem demokrasi, tentu saja termasuk Dunia Islam. Faktanya, sistem demokrasi yang dipraktikkan negara-negara kapitalis hanyalah memakmurkan dunia Barat saja atau negara-negara boneka Barat yang menjadi agen kapitalisme Barat. Sebaliknya, Dunia Ketiga tetap menderita. Perhatikan saat dunia dipimpin dan dikendalikan oleh negara-negara kapitalis penjajah, Dunia Ketiga semakin tidak sejahtera.

Berkaitan dengan ini, Joseph E Stiglitz, pemenang hadiah Nobel 2011 telah membukakan cacat demokrasi yang terjadi di Amerika. Dalam tulisannya di Vanity Fair (2011) berjudul "Of the 1\%, by the 1\%, for the 1\% ia menyatakan, bahwa di Amerika hanya 1 persen elite yang menguasai tidak kurang dari 40 persen kekayaan negeri itu. Di tengah gaya hidup glamour segelintir orang super kaya, makin banyak orang miskin dan menjadi tuna wisma. Dalam tulisan lain berjudul "The Globalization of Protest" Stiglitz menyatakan: “...perasaan bahwa 'sistem' ini telah gagal, dan keyakinan bahwa bahkan dalam suatu demokrasi, proses electoral tak bisa membetulkan kesalahan....para pengejar rente kaya menggunakan kekayaan mereka untuk memengaruhi legislasi demi melindungi dan meningkatkan kekayaan mereka ... (dan) memengaruhi arah politik.... Mereka (yakni, para pemrotes Occupy Wall Street) benar, memang ada yang salah dengan 'sistem' kita.

Pada sisi lain, kesejahteraan yang dialami negara-negara maju bukan karena faktor demokrasinya, tetapi karena eksploitasi para kapitalis terhadap dunia lain. Sebab karakter ideologi Kapitalisme adalah penjajahan (imperialisme) dan mengeksploitasi kekayaan negara-negara lain secara rakus. Dengan itulah kapitalisme tumbuh di dunia. Mereka memiskinkan development contries secara sistematis lewat berbagai cara, seperti krisis moneter, privatisasi, pasar bebas, pemberian utang, standarisasi mata uang dolar, dan mekanisme lainnya.

Tidak ada korelasi antara demokrasi dan kesejahteraan bisa dibuktikan. Beberapa negara Dunia Ketiga yang dikenal paling demokratis, seperti India atau Filipina, ternyata bukanlah negara sejahtera. Penduduknya juga banyak hidup dalam penderitaan. Indonesia, yang sering dipuji lebih demokratis pada masa reformasi, mayoritas rakyatnya juga jauh dari sejahtera. Sebaliknya, banyak negara yang dikenal tidak demokratis justru kaya, seperti Saudi Arabia, Kuwait, Bahrain, atau Brunei. Berdasarkan hal ini, demokrasi bukanlah faktor kunci sejahtera-tidaknya sebuah negara.

\subsection{Demokrasi dan stabilitas}

Anggapan demokrasi menciptakan stabilitas adalah mitos. Dalam banyak kasus, yang terjadi justru sebaliknya. Kran demokrasi yang diperluas ternyata menimbulkan banyak konflik di tengah masyarakat. Secara konseptual, hubungan konflik dan demokrasi bisa dirujuk pada ide utama demokrasi, yakni kebebasan. Ketika pintu demokrasi dibuka, banyak pihak kemudian menuntut kebebasan dan kemerdekaan atas nama bangsa, suku, kelompok. Muncul konflik antar- pihak yang bersinggungan kepentingan atas nama bangsa, suku, atau kelompoknya. Muncul pula perdebatan batasan wilayah dan kekuasaan masing-masing. Bersamaan dengan itu, muncul persaingan internal elit politik yang ingin muncul sebagai penguasa baru. Contoh nyata dalam hal ini adalah Indonesia. Masa reformasi ditandai dengan meningkatnya konflik di beberapa tempat, seperti Timor Timur, pulau Sipadan dan Ligitan (yang kemudian lepas), Aceh, Maluku, dan Papua. Konflik ini sebagian besar dipicu oleh isu keinginan untuk memisahkan diri (disintegrasi) dengan alasan kemerdekaan menentukan nasib sendiri sebagai bagian dari asas kebebasan — sebagai pilar utama demokrasi.

Hal yang sama tidak hanya terjadi di Indonesia, tetapi wilayah dunia yang lain. Demokrasi kemudian memunculkan fanatisme nasionalisme atas nama bangsa, suku, kelompok. Disintegrasi negeri-negeri eks komunis, seperti Soviet dan Yugoslavia, sebelumnya diyakini sebagai cahaya terang demokrasi. Kenyataannya, disintegrasi menimbulkan konflik yang berlarut-larut dengan korban manusia yang tidak sedikit. Konflik antar etnis pun terjadi, masing-masing dengan alasan yang sama: kemerdekaan bangsa. Belum lagi, kalau kita membicarakan korban-korban perang atas nama demokrasi yang disulut oleh negara AS. Apa yang terjadi di Irak, Libia, dan Afghanistan merupakan contoh yang jelas. Tawaran demokrasi AS ternyata menimbulkan banyak 

penderitaan bagi rakyat negara-negara tersebut. Perang atas nama demokrasi ini telah menimbulkan puluhan ribu korban manusia.

\subsection{Demokrasi dan kemajuan.}

Argumentasi demokrasi menjamin kebebasan dan kebebasan merupakan syarat kemajuan harus pula dikoreksi. Dalam bahasa demokrasi, reason (akal) bisa produktif disebabkan oleh adanya freedom (kebebasan), baik freedom of thinking (kebebasan berpikir) maupun freedom of speech (kebebasan berbicara). Keduanya itu hanya ada dalam sistem demokrasi sehingga demokrasi mutlak harus diperjuangkan. Benarkah dengan kebebasan akan diperoleh kemajuan intelektual? Tentu saja tidak sesederhana itu. Rusia pada masa kejayaan Komunisme meraih kemajuan di bidang sains dan teknologi. Mereka mampu menciptakan teknologi canggih hingga ke teknologi ruang angkasa. Padahal Komunisme sering diklaim memberangus kebebasan. Begitu pula dengan masa kejayaan Islam. Sangat jelas bukan berdasarkan sistem demokrasi. Betapa banyak karya intelektual yang dihasilkan oleh para pemikir Islam saat itu. Jutaan karya intelektual dihasilkan oleh para ulama besar seperti an-Nawawi, Ibn Taimiyah, Ibn hajar al-Asqalani, dan lainnya. Dunia Islam pun dipenuhi dengan penemuan-penemuan baru di bidang sains dan teknologi, yang diakui oleh banyak pihak. Bandingkan dengan sekarang. Sebaliknyalah yang terjadi, negeri-negeri Islam yang sebagian besar menganut sistem demokrasi mundur dalam bidang sains dan teknologi. Lihat pula kaum intelektual para penyeru demokrasi dan kebebasan di negeri Islam, berapa banyak dan bagaimana mutu tulisan mereka dibandingkan dengan ulama-ulama Islam terdahulu.

Jadi, inti masalah bukan terletak pada ada kebebasan atau tidak, tetapi apakah masyarakat itu memiliki kebiasaan berpikir produktif atau tidak. Berpikir produktif sendiri merupakan hasil dari kebangkitan berpikir yang didasarkan pada ideologi ( $m a b d a$ ) tertentu. Jadi, lepas sahih atau tidaknya ideologi yang dianut oleh suatu bangsa atau masyarakat, maka ideologi akan mendorong produktivitas berpikir bangsa tersebut. Sebab, karakter dasar ideologi adalah senantiasa ingin memecahkan persoalan manusia secara menyeluruh, sekaligus mempertahankan dan menyebarkan ideologinya. Semua itu membutuhkan berpikir yang produktif.

\subsection{Demokrasi merupakan bagian dari imperialisme}

Propaganda demokratisasi di negeri-negeri Islam tidak bisa dilepaskan dari kepentingan ekonomi dan politik negara-negara kapitalisme. Tujuan polugri negara-negara kapitalisme adalah menyebarkan ideologi kapitalisme melalui demokrasi. Tersebarnya nilai-nilai kapitalisme di dunia Islam menguntungkan negara-negara tersebut. Demokrasi dimanfaatkan untuk menjauhkan kaum muslim dari sistem dan nilai Islam. Sebab, demokrasi menyerahkan kedaulatan ke tangan manusia, sementara dalam Islam, kedaulatan berada di tangan Allah Swt. Acapkali tampak bahwa demokrasi digunakan untuk memerangi kaum Muslim di beberapa kawasan Timur Tengah. Atas nama menegakkan demokrasi dan memerangi terorisme, negeri-negeri muslim diserang dan dihancurkan, seperti yang terjadi di Irak, Libia, Suriah, dan Afganistan.

\section{TRANSFORMASI POLITIK ISLAM DALAM SISTEM DEMOKRASI}

Proses reformasi di Indonesia 20 tahun lalu (1998) diharapkan membawa proses perubahan luas dan mendasar pada kehidupan bangsa Indonesia. Setelah berjalan sekian lama perubahan itu tidak nampak terjadi, baik berkenaan dengan kesejahteraan rakyat, kemajuan ekonomi, pendidikan, supremasi hukum, kehidupan sosial, dan politik. Perubahan mengalami stagnasi jika tidak mau dikatakan menjadi lebih buruk. Hal itu karena reformasi tidak dimaksudkan untuk melakukan perubahan fundamental. Artinya, kehidupan sebelum dan sesudah reformasi tetap sama, yaitu tatanan kehidupan sekuler, praktik korupsi meningkat tajam dan tersebar ke seluruh pelosok negeri, kerusakan lingkungan tak bisa dielakkan, pornografi dan pornoaksi tak terkendali, dan angka kemiskinan semakin tinggi dan mewarnai potret buram Indonesia. Di samping itu, SDA yang seharusnya diperuntukkan bagi peningkatan kesejahteraan rakyat justru berpindah ke dalam cengkeraman asing dan aseng. Pengaruh kekuatan asing dan aseng terasa sangat kuat mempengaruhi kebijakan di negeri ini. Oleh sebab itu, transformasi politik Islam dalam sistem demokrasi berkaitan dengan proses perubahan masyarakat (social engineering) menuju Islam. dengan memperhatikan: Pertama, pemahaman terhadap fakta masyarakat dari sudut pandang Islam. Kedua, pemahaman terhadap metode perubahan yang digunakan berdasarkan Islam. Ketiga, pemahaman tentang gambaran masyarakat ideal yang hendak diwujudkan.

Proses transformasi dalam Islam senantiasa dikaitkan dengan keteladanan Rasulullah saw. Dalam mengubah masyarakat Arab jahiliyyah menuju Islam. Berdasarkan proses transformasi sosial dan politik yang dilakukan Rasulullah saw. maka dapat diperhatikan proses berikut, yaitu:

\subsection{Transformasi pemahaman Islam.}

Rasul saw. membina masyarakat dengan aqidah Islam sebagai mabda-u lilhayah. Upaya ini untuk membentuk kepribadian muslim melalui proses internalisasi dan eksternalisasi nilai-nilai Islam sebagai konsepsi kehidupan dan praktik. Tahap ini mewujudkan pribadi shalih dan amanah yang siap berinteraksi dengan masyarakat. berupaya memahamkan Islam sebagai konsepsi hidup dan mengajak masyarakatnya mempraktikkan Islam dalam kehidupan sebagai wujud ibadah kepada Allah swt.

\subsection{Interaksi dengan masyarakat.}

Kesadaran bahwa Islam itu kebaikan maka setiap muslim shalih berupaya untuk mencerdaskan masyarakatnya dengan Islam. Tujuannya menggugah kesadaran (pemikiran dan perasaan) masyarakat terhadap realitas buruk yang terjadi dalam realitas sosial agar masyarakat tergugah untuk menjadikan penerapan nilai dan syariat Islam sebagai persoalan utama dalam hidupnya. Pada aspek ini terjadi shira' al-fikr dengan mengkritisi isme-isme yang keliru dengan sudut pandang Islam, seperti mengkritisi kapitalisme-sekularisme-liberalisme, sosialisme-komunisme, dan seluruh derivasinya. Dilanjutkan dengan Kifahus siyasiy merupakan proses perjuangan politis menghadapi negara-negara kapitalisme-imperialisme sekuler yang melakukan neoimperialisme dengan mendominasi-menghegemoni negeri Muslim dalam bidang ekonomi, sosial-politik, militer, sosial-budaya, dan mengungkap rencana curang terhadap umat Muslim. Di samping itu, melakukan tabanniy mashalih al-ummat, yakni aktivitas mengadopsi dan menetapkan kemaslahatan umat dengan cara melayani dan mengatur urusan umat sesuai dengan hukum dan nilai syariat. 
Kondisi ini adalah kondisi kesiapan seluruh elemen masyarakat untuk mengimplementasikan Islam mengatur seluruh aspek kehidupan masyarakat, baik Muslim maupun bukan. Penerapan Islam memberikan jaminan bagi Muslim maupun non-muslim untuk hidup berdampingan damai dan sejahtera, karena Islam itu rahmatan lil 'alamiin.

Memperhatikan proses perubahan masyarakat di atas maka perubahan yang terjadi bersifat alamiah dengan segenap kesadaran akal sehat masyarakat karena dikehendaki seluruh komponen masyarakat. Model transformasi tersebut dilakukan Rasulullah saw. bersama para sahabatnya.

\section{PERBEDAAN ISLAM DAN DEMOKRASI}

Berfikir kritis dan mendasar tentang Islam dan demokrasi maka bagi seorang Muslim akan menjadikan Islam sebagai tolak ukur dalam menimbang demokrasi. Hal ini disebabkan seorang muslim terikat dengan seluruh perangkat tatanan keyakinan Islam dan nilai-nilai yang terdapat di dalamnya. Berkaitan dengan Islam dan demokrasi, kita dapat melihat perbedaan tersebut dalam 7 aspek mendasar, yaitu sistem, asas, pembuat hukum atau Undang-Undang, sumber hukum, sumber kekuasaan, status kepala negara, dan suara mayoritas. Perhatikan Tabel 1.

Tabel 1. Perbedaan Islam Dan Demokrasi

\begin{tabular}{|c|c|c|c|}
\hline No. & DASAR PERBEDAAN & ISLAM & DEMOKRASI \\
\hline 1. & Sistem & Islam & Demokrasi \\
\hline 2. & Asas & $\begin{array}{l}\text { Kedaulatan berada di tangan Allah swt ( Hukum } \\
\text { syara') }\end{array}$ & $\begin{array}{l}\text { Kedaulatan berada di tangan rakyat (dari rakyat, oleh } \\
\text { rakyat, dan untuk rakyat) }\end{array}$ \\
\hline 3. & $\begin{array}{l}\text { Pembuat Hukum atau } \\
\text { Undang-Undang }\end{array}$ & $\begin{array}{l}\text { Allah swt. dan khalifah dan rakyat menjalankan } \\
\text { hukum Allah swt. }\end{array}$ & $\begin{array}{l}\text { Rakyat melalui wakil rakyat di DPR berhak membuat } \\
\text { dan mengganti UU (fungsi legislative) }\end{array}$ \\
\hline 4. & Sumber Hukum & Al-Quran, As-Sunnah, Ijma shahabat, dan Qiyas & UUD dan UU yang dibuat oleh wakil rakyat \\
\hline 5. & Sumber Kekuasaan & $\begin{array}{l}\text { Kepala negara dan wakil rakyat dipilih warga } \\
\text { negara }\end{array}$ & Kepala negara dan wakil rakyat dipilih warga negara \\
\hline 6. & Status Kepala negara & $\begin{array}{l}\text {-Bukan wakil dan bukan mandataris Tuhan } \\
\text { - Pelaksana Syariat Allah swt. }\end{array}$ & Mandataris Rakyat untuk melaksanakan UUD dan UU \\
\hline 7. & Suara Mayoritas & $\begin{array}{l}\text { Suara mayoritas atau minoritas tidak berfungsi } \\
\text { untuk membuat hukum }\end{array}$ & Berfungsi membuat hukum \\
\hline
\end{tabular}

\section{PERBEDAAN MUSYAWARAH (SYURA) DALAM ISLAM DAN DEMOKRASI}

Demikian pula, dalam kaitan dengan Islam dan demokrasi berkenaan dengan musyawarah (syura), maka terdapat 5 aspek perbedaan mendasar, yaitu ideologi, asas, tujuan, objek, dan kedudukan. Perhatikan Tabel 2.

Tabel 2. Perbedaan Musyawarah (Syura) dalam Islam dan Demokrasi

\begin{tabular}{|c|c|c|c|}
\hline No. & $\begin{array}{l}\text { LANDASAN } \\
\text { PERBEDAAN }\end{array}$ & ISLAM & DEMOKRASI \\
\hline 1. & IDEOLOGI & Aqidah Islam & Kapitalisme-liberalisme \\
\hline 2. & ASAS & $\begin{array}{l}\text { - } \quad \text { Penyatuan mondial dan akhirat } \\
\text { - } \quad \text { Islam sebagai agama mengurusi } \\
\text { seluruh aspek kehidupan manusia (privat } \\
\text { domain dan public domain) }\end{array}$ & $\begin{array}{l}\text { - } \quad \text { Sekularisme sebagai faham yang memisahkan agama dari } \\
\text { ruang publik (public domain) (sosial, ekonomi, politik, dan } \\
\text { pemerintahan) } \\
\text { - } \quad \text { Agama urusan individu (privat domain) }\end{array}$ \\
\hline 3. & TUJUAN & $\begin{array}{l}\text { Pengambilan pendapat dalam syura } \\
\text { (musyawarah) dalam Islam dilaksanakan } \\
\text { dalam rangka mengetahui dan/atau } \\
\text { melaksanakan hukum Allah SWT. }\end{array}$ & $\begin{array}{l}\text { - Pengambilan pendapat dalam sistem demokrasi dilaksanakan } \\
\text { untuk mewujudkan apa yang disebut dengan kedaulatan rakyat. } \\
\text { Prinsip ini mengajarkan bahwa rakyatlah yang memiliki kehendak. } \\
\text { Hal ini terutama nampak di bidang hukum. Maka musyawarah } \\
\text { dalam sistem demokrasi diadakan terutama untuk menetapkan } \\
\text { hukum atau peraturan yang hendak diterapkan di tengah } \\
\text { masyarakat, dengan atau tanpa mempertimbangkan ajaran agama. } \\
\text { - Syariat agama hanya dianggap sebagai salah satu, bukan satu- } \\
\text { satunya sumber rujukan. Karena itu wajar saja bila produk hukum } \\
\text { dalam sistem demokrasi sering kali bertabrakan dengan syariat } \\
\text { Islam. }\end{array}$ \\
\hline 4. & OBJEK & $\begin{array}{l}\text { Syura dalam ajaran Islam dilaksanakan } \\
\text { tidak dalam masalah tasyri } \square \text { (penetapan } \\
\text { hukum syariat), karena penetapan hukum } \\
\text { dilakukan melalui nash-nash syara } \square \text { yang } \\
\text { tegas dan jelas, serta ijtihad syar } \square \text { iy para } \\
\text { mujtahid. Musyawarah dilakukan dalam } \\
\text { perkara mubah (teknis pelaksanaan suatu } \\
\text { perkara atau strategi), }\end{array}$ & $\begin{array}{l}\text { - Pengambilan pendapat dalam sistem demokrasi dilakukan } \\
\text { dalam semua perkara, baik itu menyangkut masalah teknis, } \\
\text { strategis, maupun penerapan hukum. } \\
\text { - } \quad \text { Pengambilan keputusan yang diambil dengan voting } \\
\text { menjadikan kelompok yang memiliki anggota terbanyak itulah yang } \\
\text { selalu menang. Apalagi jika terjadi money politics, maka hukum atau } \\
\text { peraturan yang dihasilkan tentu saja akan cenderung berpihak } \\
\text { kepada kelompok terbanyak. }\end{array}$ \\
\hline 5. & KEDUDUKAN & $\begin{array}{l}\text { Sementara syura dalam Islam hukumnya } \\
\text { sunnah. Dilakukan lebih baik, tidak } \\
\text { dilakukan tidak menjadi masalah, maka } \\
\text { pengambilan keputusan, apalagi itu } \\
\text { menyangkut hukum dalam Islam dapat } \\
\text { dilakukan dengan cepat, praktis dan benar } \\
\text { karena berlandaskan pada nash-nash yang }\end{array}$ & $\begin{array}{l}\text { Pengambilan pendapat mayoritas dalam sistem demokrasi harus } \\
\text { selalu dilakukan, sehingga acap kali terjadi satu produk hukum } \\
\text { memerlukan pembahasan bertahun-tahun. Di samping itu undang- } \\
\text { undang yang telah dihasilkan bersusah payah itupun suatu saat } \\
\text { dapat berubah, jika parlemen mendatang dikuasasi partai } \\
\text { berhaluan lain menghendaki. }\end{array}$ \\
\hline
\end{tabular}

pasti benar. 
JKPIs, Vol. 1 No. 1, 2018 |6

Hal yang penting harus dipahami dalam implementasi pengambilan keputusan dalam musyawarah (syura) dalam Islam adalah dengan memperhatikan pokok-pokok pikiran yang berkaitan: masalah hukum syariat, masalah definisi non-syariat dan teknologi, masalah penjelasan aktivitas, Implementasi syura dalam mengambil keputusannya dijelaskan pada Tabel 3.

Tabel 3. Implementasi Musyawarah (Syura)

\begin{tabular}{|c|c|c|}
\hline No & Pokok pikiran & Penjelasan \\
\hline 1 & Masalah Hukum Syariat & $\begin{array}{l}\text { - Hukum syariat dasarnya adalah dalil syariat, maka yang menentukan keputusan adalah kekuatan } \\
\text { dalil. Jika dalilnya qath'iy (pasti/jelas) maka tidak dibahas dan segera dilaksanakan. } \\
\text { - Jika dalilnya dzanniy (tidal pasti/belum jelas) maka keputusannya bergantung pada yang ahsan } \\
\text { (paling baik) berdasarkan pada aqwaatuhu daliyluhu dan abyaanuhu fahmuhu (paling jelas } \\
\text { pemahamannya). Dua parameter ini yang menentukan pendapat yang paling mendekati kebenaran. }\end{array}$ \\
\hline 2. & $\begin{array}{l}\text { Masalah Definisi non- } \\
\text { syariat dan sain teknologi }\end{array}$ & $\begin{array}{l}\text { - keputusan ditentu oleh pendapat yang benar (ra'yu shawab) } \\
\text { - masalah sain teknologi ditentukan oleh para ahli dalam masing-masing bidang. } \\
\text { - tidak diambil pendapat mayoritas }\end{array}$ \\
\hline 3. & $\begin{array}{l}\text { Masalah Penjelasan } \\
\text { Pelaksanaan Aktivitas }\end{array}$ & $\begin{array}{l}\text { Keputusan dikembalikan kepada pendapat mayoritas. Praktik Rasulullah saw. saat melakukan } \\
\text { musyawarah tentang perang Uhud. Musyawarah tidak dilakukan dalam menentukan hukum tentang } \\
\text { perang dan strategis perang, tetapi tentang cara melaksanakan perang menghadapi musuh, pakah } \\
\text { dilakukan di luar kota Madinah atau di dalam kota Madinah. Rasul saw. dan para sahabat senior } \\
\text { cenderung untuk dilakukan di dalam kota Madinah, tetapi mayoritas menghendaki di luar kota } \\
\text { Madinah. Lalu Rasul saw. memutuskan untuk dilakukan di luar kota Madinah sesuai dengan pendapat } \\
\text { mayoritas. Pendapat para sahabat senior yang ahli perang tidak beliau ambil karena masalahnya bukan } \\
\text { tentang strategi perang tetapi melaksanakan aktivitas yang akan dilakukan bersama dengan umat. Jadi, } \\
\text { masalah inilah yang masuk dalam perkara yang dapat dimusyawarahkan. }\end{array}$ \\
\hline
\end{tabular}

\section{PERBEDAAN PEMILU DALAM ISLAM DAN DEMOKRASI}

Dalam kaitan Islam dan demokrasi yang sering dibahas adalah berkaitan dengan pemilu. Terdapat 9 perbedaan yang signifikan antara keduanya, meliputi perbedaan dari sudut kedudukan dan fungsi pemilu, tujuan pemilu, keterlibatan rakyat dalam pemilu, yang berhak dipilih dalam pemilu, kepala negara, fungsi dan tugas wakil rakyat, peristilahan kepala negara, pembatasan jabatan kepala negara, dan pemberhentian kepala negara. Berkenaan dengan hal itu, perhatikan Tabel 4.

Tabel 4. Perbedaan Pemilu Dalam Islam dan Demokrasi

\begin{tabular}{|c|c|c|c|}
\hline No & POKOK BAHASAN & ISLAM & DEMOKRASI \\
\hline 1. & Kedudukan, Fungsi Pemilu & $\begin{array}{l}\text { - Salah satu cara (uslub) memilih khalifah } \\
\text { dengan bai'at sebagai metode pengangkatan } \\
\text { khalifah } \\
\text { - Pelaksanaan pemilu mubah (boleh) } \\
\text { - Kedaulatan membuat hukum di tangan } \\
\text { syara' } \\
\text { - Fungsi kekuasaan sebagai pelaksanaan } \\
\text { syariat }\end{array}$ & $\begin{array}{l}\text { - Metode (thariqah) mewujudkan kedaulatan } \\
\text { rakyat } \\
\text { - Pelaksanaan pemilu wajib } \\
\text { - Wakil rakyat berfungsi sebagai legislatif } \\
\text { (membuat hukum dan undang-undang) } \\
\text { - Kedaulatan di tangan rakyat berdasarkan suara } \\
\text { mayoritas }\end{array}$ \\
\hline 2. & Tujuan Pemilu & & \\
\hline 3. & $\begin{array}{l}\text { Keterlibatan Rakyat Dalam } \\
\text { Pemilu }\end{array}$ & $\begin{array}{l}\text { - Seluruh rakyat berhak memilih wakil rakyat } \\
\text { untuk duduk di Majelis Ummat berdasarkan } \\
\text { suara mayoritas } \\
\text { - Nonmuslim berhak memilih sesama mereka } \\
\text { sebagai anggota Majelis Ummat } \\
\text { - Kepala negara (khalifah) hanya dipilih oleh } \\
\text { warga negara yang muslim }\end{array}$ & $\begin{array}{l}\text { - Seluruh rakyat berhak memilih wakil rakyat untuk } \\
\text { duduk di DPR dan kepala negara (presiden) } \\
\text { berdasarkan suara mayoritas } \\
\text { - Dalam pemilihan presiden (kepala negara) tidak } \\
\text { membedakan muslim dan nonmuslim }\end{array}$ \\
\hline 4. & Yang Berhak Dipilih & $\begin{array}{l}\text {-untuk duduk di majelis ummat maka kaum } \\
\text { muslim memilih dari kalangan muslim saja, } \\
\text { begitu pula kaum nonmuslim memilih wakil } \\
\text { dari kalangan non muslim saja } \\
\text { - untuk menjadi kepala negara (khalifah) } \\
\text { maka syaratnya harus muslim saja } \\
\text { - nonmuslim tidak bisa menjadi khalifah } \\
\text { (kepala negara) }\end{array}$ & $\begin{array}{l}\text {-siapapun berhak dipilih untuk menjadi wakil } \\
\text { rakyat dan menjadi presiden (kepala negara) }\end{array}$ \\
\hline 5. & Kepala Negara & $\begin{array}{l}\text {-Kepala negara (khalifah) diangkat melalui } \\
\text { bai'at untuk melaksanakan syariat Islam } \\
\text { dengan berpedoman pada Al-Quran dan } \\
\text { Sunnah Rasulullah saw. } \\
\text { - Berdasarkan suara mayoritas atau ahlul hilli } \\
\text { wal aqdhi } \\
\text { - Beragama Islam }\end{array}$ & $\begin{array}{l}\text { - Kepala negara diangkat untuk menjalankan UUD } \\
\text { dan UU } \\
\text { - berdasarkan suara mayoritas } \\
\text { - Umumnya kepala negara di negara Eropa dan } \\
\text { Amerika beragama Nasrani (Katolik/protestan) }\end{array}$ \\
\hline 6. & $\begin{array}{l}\text { Fungsi dan Tugas Wakil } \\
\text { Rakyat }\end{array}$ & $\begin{array}{l}\text {-Wakil rakyat berfungsi untuk menyampaikan } \\
\text { aspirasi dan kepentingan rakyat } \\
\text {-Melakukan fungsi kontrol terhadap }\end{array}$ & $\begin{array}{l}\text {-Wujud dari kedaulatan rakyat yang berfungsi } \\
\text { sebagai legislatif. }\end{array}$ \\
\hline & & $\begin{array}{l}\text { pelaksanaan pemerintahan yang dilakukan } \\
\text { oleh khalifah }\end{array}$ & $\begin{array}{l}\text {-Hukum dan UU yang dibuat di DPR merupakan hal } \\
\text { yang harus dilaksanakan oleh kepala } \\
\text { negara/kepala pemerintahan }\end{array}$ \\
\hline 7. & Peristilahan Kepala Negara & $\begin{array}{l}\text { - Khalifah, Amirul Mukminin, Imamul } \\
\text { Mukminin } \\
\text { - Tidak bisa diganti dengan istilah atau nama } \\
\text { lain }\end{array}$ & - - Presiden, Perdana Menteri \\
\hline
\end{tabular}


JKPIs, Vol. 1 No. 1, $2018 \mid 7$

\begin{tabular}{|c|c|c|c|}
\hline No & POKOK BAHASAN & ISLAM & DEMOKRASI \\
\hline \multirow[t]{2}{*}{8.} & $\begin{array}{l}\text { Pembatasan Jabatan Kepala } \\
\text { Negara }\end{array}$ & $\begin{array}{l}\text {-Tidak dibatasi waktu bahkan memungkinkan } \\
\text { seumur hidup, seperti Abu Bakar shidiq, } \\
\text { Umar bin Kjhatthab, Ustman Bin Affan, Ali } \\
\text { bin Abi Thalib }\end{array}$ & $\begin{array}{l}\text {-Jabatan dibatasi hanya } 4 \text { atau } 5 \text { tahun sesuai } \\
\text { dengan ketentuan UU }\end{array}$ \\
\hline & & $\begin{array}{l}\text { - batasnya adalah sepanjang khalifah } \\
\text { konsisten dalam pelaksanaan syariat Islam } \\
\text { dengan tetap merujuk pada Al-Quran dan } \\
\text { Sunnah Nabi saw. } \\
\text {-Jika khalifah menyimpang dan setelah } \\
\text { dilakukan koreksi tidak mau kembali kepada } \\
\text { sumber hukum Islam maka khalifah harus } \\
\text { diganti meskipun usia kekuasaannya masih } \\
\text { baru }\end{array}$ & $\begin{array}{l}\text {-Dapat dipilih kembali untuk masa waktu yang } \\
\text { sama }\end{array}$ \\
\hline 9. & $\begin{array}{l}\text { Pemberhentian } \\
\text { Negara }\end{array}$ & $\begin{array}{l}\text { - Rakyat tidak berhak memecat khalifah, } \\
\text { kecuali melakukan penyimpangan } \\
\text { - Pemecatan khalifah jika menyimpang } \\
\text { dilakukan oleh lembaga Mahkamah } \\
\text { Madzalim setelah meninjau ulang } \\
\text { penyimpangan yang dilakukannya } \\
\text { - Jika mekanisme di atas tidak berfungsi maka } \\
\text { rakyat dapat menurunkan khalifah dengan } \\
\text { kekuatan senjata }\end{array}$ & $\begin{array}{l}\text { Rakyat berhak untuk memecat kepala negara sesuai } \\
\text { dengan UU atau tidak karena UU akan berubah } \\
\text { sesuai dengan kehendak rakyat }\end{array}$ \\
\hline
\end{tabular}

\section{KESIMPULAN}

Mencermati sistem demokrasi secara teoretis konseptual dan praktik maka didapati bahwa dalam sistem demokrasi menyimpan self-destructive dan cacat bawaan, yaitu berkaitan dengan konsep kedaulatan (hak membuat hukum) berada di tangan rakyat. Hal itu berarti bahwa rakyat (manusia) merupakan sumber kebenaran sehingga suara rakyat merupakan kebenaran itu sendiri dan sering disejajarkan menjadi suara rakyat adalah suara Tuhan. Padahal pada hakikatnya manusia memiliki sejumlah kelemahan dalam memahami hakikat kebenaran dan kebenaran yang ditetapkan manusia bersifat relatif. Relativitas kebenaran pendapat manusia menunjukkan bahwa pada waktu dan tempat berbeda maka akan selalu mengalami perubahan. Itu maknanya bahwa hukum yang bersumber dari manusia akan selalu mengalami perubahan seiring dengan perubahan tempat dan waktu.

Adapun dalam Islam, secara konseptual dan praktik menunjukkan bahwa kedaulatan berada di tangan Allah swt., Pencipta dan Penguasa manusia dan alam semesta. Hal itu bermakna bahwa Allah swt. mengetahui yang terbaik bagi manusia dan mencegah manusia terjerumus kepada kesalahan dan kekeliruan. Dalam kaitan ini, kebenaran itu bersumber dari Allah swt. (Al-quran dan Sunnah Nabi saw.) dan semua manusia adalah hamba-Nya yang diperintahkan untuk mengikuti nilai, aturan, dan hukum yang hanya bersumber dari-Nya, bukan yang lain sebagai bentuk pengabdian kepada-Nya. Dengan demikian, hukum Allah bersifat tetap dan pasti dan tidak bersifat relatif kebenarannya. Hal itu menunjukkan bahwa pada waktu dan tempat yang berbeda maka hukum tidak mengalami perubahan. Berdasarkan hal tersebut maka tampak perbedaan yang mendasar/paradigmatik dan signifikan antara Islam dan demokrasi sehingga menyamakan dan mengolaborasikan keduanya merupakan aktivitas yang tidak bermakna karena keduanya sangat jelas berbeda, bagaikan air dan minyak.

Melakukan proses transformasi politik Islam dalam masyarakat muslim di Indonesia melalui pintu demokrasi tentu menghasilkan kontraksi dan kontradiksi karena akan terdapat sejumlah aktivitas yang saling bertentangan antarkeduanya. Oleh sebab itu proses transformasi politik yang diharapkan dalam tipologi masyarakat muslim Indonesia adalah proses mencerdaskan kaum muslim dengan Islam sebagai mabda'u lil hayah (konsepsi mendasar bagi kehidupan), sama seperti seorang sekularis memahami secara mendasar tentang Kapitalisme-demokrasi sebagai ideologi kehidupan bagi mereka. Oleh sebab itu, kebangkitan sebuah masyarakat sangat bergantung pada kebangkitan pemikirannya dan kualitas taraf berfikir masyarakat tersebut tentang manusia, alam semesta, dan kehidupan, serta keterkaitan antara ketiganya. Inilah yang melahirkan 3 cara pandang hidup (mabda'u lil hayah), Islam, Kapitalisme-Sekularisme, dan Sosialisme-Komunisme. Proses transformasi yang hakiki adalah melakukan perubahan dalam cara pandang tentang kehidupan, baik point view maupun world of view.

\section{REFERENSI}

Al-Mawardiy. Al-ahkaamu al-suthaaniyyah wa al-wilaayaat al-diyniyyah. Beirut-Libanon: Daaru al-kutub al-'alamiyyah Al-Mawardiy. Al-ahkaamu al-suthaniyyah wa al-wilaayaat al-diyniyyah. Beirut-Libanon: Daaru al-kutub al-'alamiyyah

Azhar, Muhammad Ali. (2012). Relasi Pengusaha-Penguasa Dalam Demokrasi: Fenomena Rent Seeker Pengusaha Jadi Penguasa. Jurnal PUBLICA, 2(1) 403.

Basarmin, D. (1994). Secrets, Lies and Democracy (Interviews with Noam Chomsky).

Blum, W. (2013). America's Deadliest Export: Democracy - the Truth about US Foreign Policy and Everything Else. New York: Zed Books.

Kaplan, R.D. (2000). The Coming Anarchy, Shattering The Dreams of The Post Cold War. United States of America: Random House New York.

Lavelle, A. (2008). The Death of Social Democracy, Political Consequences in the 21st Century. England: Ashgate Publishing Limited.

National Intelligence Council. (2004). Mapping The Global Future, Report of the National Intelligence Council's 2020 Project Based on consultations with nongovernmental experts around the world.

Stiglitz, Joseph E. (2011). The Globalization of Protest. Project Syndicate.

Toffler, Alvin. (1990). Powershift: Knowledge, Wealth, And Violence At The Edge of The 21st Century. Amerika Serikat: Bantam Book. 